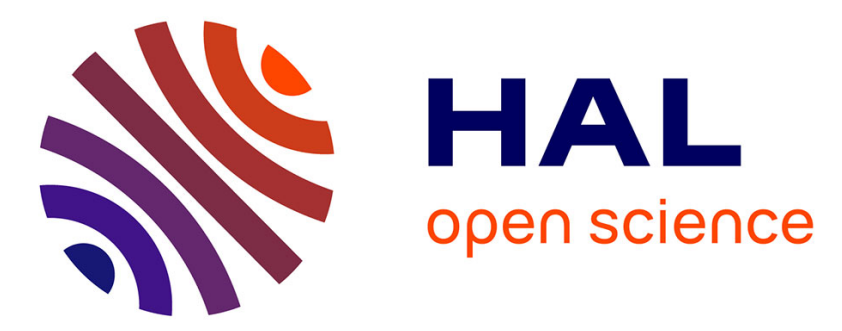

\title{
Anthropogenic particles in the stomach contents and liver of the freshwater fish Squalius cephalus
}

France Collard, Johnny Gasperi, Bernard Gilbert, Gauthier Eppe, Sam Azimi, Vincent Rocher, Bruno Tassin

\section{- To cite this version:}

France Collard, Johnny Gasperi, Bernard Gilbert, Gauthier Eppe, Sam Azimi, et al.. Anthropogenic particles in the stomach contents and liver of the freshwater fish Squalius cephalus. Science of the Total Environment, 2018, 643, pp.1257 - 1264. 10.1016/j.scitotenv.2018.06.313 . hal-01830268

\section{HAL Id: hal-01830268 \\ https://hal-enpc.archives-ouvertes.fr/hal-01830268}

Submitted on 19 Apr 2019

HAL is a multi-disciplinary open access archive for the deposit and dissemination of scientific research documents, whether they are published or not. The documents may come from teaching and research institutions in France or abroad, or from public or private research centers.
L'archive ouverte pluridisciplinaire HAL, est destinée au dépôt et à la diffusion de documents scientifiques de niveau recherche, publiés ou non, émanant des établissements d'enseignement et de recherche français ou étrangers, des laboratoires publics ou privés. 
6 France Collard $^{1 *}$, Johnny Gasperi ${ }^{1}$, Bernard Gilbert ${ }^{2}$, Gauthier Eppe ${ }^{2}$, Sam Azimi ${ }^{3}$, Vincent $7 \quad$ Rocher $^{3}$, Bruno Tassin ${ }^{1}$

8

9

$10{ }^{1}$ Laboratoire Eau Environnement et Systèmes urbains (LEESU), Université Paris-Est Créteil, Ecole

11 des ponts Paristech, AgroParisTech, 61 avenue du Général de Gaulle, 94010 Cedex Créteil, France.

12 Inorganic Analytical Chemistry Laboratory, B6c, Department of Chemistry, University of Liege, 134000 Liege, Belgium.

$14{ }^{3}$ Syndicat Interdépartemental pour l'Assainissement de l'Agglomération Parisienne (SIAAP), 15 Direction du Développement et de la Prospective, 82 Avenue Kléber, 92700 Colombes, France.

$17 *$ Corresponding author:

18 Laboratoire Eau Environnement et Systèmes Urbains (LEESU)

19 Université Paris-Est Créteil (UPEC)

20 61, Avenue du Général de Gaulle 94010 Créteil, France

21 francecollard16@gmail.com, gasperi@u-pec.fr

22 phone: +33145171621

23 Current address: Norwegian Polar Institute (NPI), Fram Center, 9296 Troms $\varnothing$, Norway 
Anthropogenic particles (APs) are a very broad category of particles produced directly or indirectly

by human activities. Their ingestion by biota is well studied in the marine environment. In contrast, studies on AP ingestion in wild freshwater organisms are scarce despite high contamination levels in some rivers and lakes. In this study, we aimed to evaluate the ingestion of APs and the possible occurrence of APs in the liver and muscle of a freshwater fish, Squalius cephalus, from the Parisian conurbation. After isolation, the particles were analyzed using Raman spectroscopy. In sixty stomachs, eighteen APs were found, half of which were plastics and the other half were dyed particles. Twenty-five percent of sampled individuals had ingested at least one AP. The mean length of the APs was $2.41 \mathrm{~mm}$. No significant difference was found between the sites upstream and downstream of Paris. Additionally, 5\% of sampled livers contained one or more APs, which were characterized as microplastics (MPs). No APs were found in the muscle tissue. The majority of APs isolated from stomach contents were fibers, which is similar to the findings of a previous river contamination study. This highlights that fish could be more exposed to fibers than previously thought and that more studies on the impacts of fiber ingestion are required. Despite their low occurrence, MPs are reported, for the first time, in the liver of a wild freshwater fish species. While the pathways and impacts are still unknown, MPs also occur in liver of marine mollusks and fish. Physiological in vitro studies are needed to better evaluate the impacts of such phenomena.

44 Keywords

46 Microplastics, fibers, Seine River, European chub, muscle, liver 
50 Anthropogenic particles (APs) are a very broad category of particles produced directly or indirectly

51 by human activities, thus showing an anthropogenic origin. In this study, APs are defined as small

52 pieces - fragments or fibers - with an anthropogenic origin, such as plastic, dyed particles or textile

53 fibers, regardless of their size. All textile fibers have been handled by humans (e.g., dyed) and thus

54 have an anthropogenic origin, regardless of whether their basic composition is natural. All seas and

55 oceans are contaminated by APs, including plastics (Cózar et al., 2014), and so are a large number

56 of organisms (Kühn et al., 2015). Numerous studies, reviews and books (Bergmann et al., 2015)

57 report the extent of this phenomenon, particularly plastic pollution and its impact on marine

58 environments. However, although marine environments have been well studied regarding APs

59 (mainly plastics), knowledge about freshwater contamination by APs and their ecological impacts

60 remains scarce (Dris et al., 2015b). Yet, rivers continue to be the main source of microplastics

61 (MPs) (<5 mm, (Arthur et al., 2009)) to coastal ecosystems (Lima et al. 2014; Lebreton et al. 2017).

62

63 Several studies conducted in freshwater (Dris et al., 2015a; Faure et al., 2015), such as in the Seine

64 River (Gasperi et al., 2014), the River Thames (Morritt et al., 2014), the Danube River (Lechner et

65 al., 2014), the Yangtze and Hanjiang Rivers (Wang et al., 2017), the Laurentian Great Lakes

66 (Eriksen et al., 2013) and in several Chilean rivers (Rech et al., 2014), showed that freshwater is

67 contaminated, sometimes highly contaminated, by APs, especially plastics. Among others, a study

68 by Lechner et al. (2014) calculated that, in the Danube River, the global plastic mass for both MPs

69 and macroplastics was higher than the fish larvae mass. In the U.S.A., over 4 million particles are

70 estimated to be released every day from one Californian wastewater treatment plant (Mason et al.,

71 2016). 
73 High AP concentrations could likely lead to their ingestion by aquatic organisms. Studies focusing

74 on freshwater biota contamination are very scarce. Few studies mention AP or MP ingestion by 75 wild fish species (Faure et al., 2012, 2015; Sanchez et al., 2014; Phillips and Bonner, 2015; Pazos 76 et al., 2017; Silva-Cavalcanti et al., 2017; Vendel et al., 2017) or marine mammal species

77 (Denuncio et al., 2011), and even these have focused only on stomach contents.

78 Aquatic organisms can suffer mechanical damage from ingestion of APs, e.g., obstruction or 79 starvation, as has been shown in marine mammals and birds (Beck and Barros, 1991; Pierce et al., 80 2004; Jacobsen et al., 2010). Furthermore, aquatic organisms, including fish, can also be impacted 81 by toxicological issues including pollutant transfer (Cedervall et al., 2012; Rochman et al., 2013;

82 Wright and Kelly, 2017) or translocation of MPs into other organs such as the liver (Avio et al., 83 2015; Collard et al., 2017a).

85 In this study, we analyzed the ingestion of APs by the chub Squalius cephalus in two highly 86 anthropized rivers, the Marne and the Seine Rivers, which both cross the Greater Paris Megacity.

87 The chub has not been studied so far in the context of AP pollution despite its omnipresence in 88 European rivers and its abundant population (Freyhof, 2014). Due to its ubiquity, the chub could 89 be a bioindicator for AP pollution in rivers. This species has a minor economic interest, but its 90 consumption by Europeans was at its maximum in 2011 (FAO, 2011). Adults are solitary, and 91 juveniles are gregarious, but both are pelagic. Generally, they feed on insects, plants and 92 crustaceans such as crayfish (Balestrieri et al., 2006; Mann, 1976; Michel and Oberdorff, 1995).

93 However, their diet varies with age and season. In the Babuna River (Republic of Macedonia), they 94 mainly feed on algae (Chrysophyceae) and insect larvae (Ephemeroptera and Plecoptera) in spring, 95 on algae (Chrysophyceae) in summer and autumn and on diatoms and other insect larvae 
96 (Chironomidae) in winter (Nastova-Gjorgjioska et al., 1997). Young individuals eat primarily

97 insects (Mann, 1976), while adults generally feed on plants or crayfish and on other fish,

98 particularly in winter (Michel and Oberdorff, 1995). Moreover, the chub adapts its diet to its habitat

99 (Piria et al., 2005). For example, in Croatia, depending on the river, the diet -dominant components 100 are Diptera (insects), cladocerans (Djinova, 1976 cited in Piria et al., 2005), detritus (Adamek and

101 Obrdlik, 1977) or zoobenthos (Losos et al., 1980).

102

103 AP contamination of the Greater Paris Megacity rivers, e.g., the Seine and Marne Rivers, was 104 studied during a 19-month period between April 2014 and December 2015, excluding January and 105 August 2015, from upstream to downstream suburbs crossing the very dense part of the urban area 106 (Dris et al., 2018). Because of its sprawling population (12 million inhabitants), Greater Paris exerts 107 a high anthropogenic pressure on rivers and, therefore, is a site of great interest for assessing the 108 ingestion of APs by Squalius cephalus. The sampling was done along the continuum of the Seine 109 and Marne Rivers, allowing a comparison between the upstream and the downstream suburbs of 110 Paris. Our objectives were to evaluate the ingestion of APs, including microplastics, by European 111 chubs caught within the Parisian conurbation and to determine whether APs translocate into muscle 112 or liver tissue in this species.

114 Materials and methods

116 Sampling

118 Sixty freshwater fish of the species Squalius cephalus (mean length \pm SD: $296 \mathrm{~mm} \pm 62$, mean 119 weight \pm SD: $340 \mathrm{~g} \pm 239$ ) were electrofished in the Marne and Seine Rivers around Paris (Fig. 1), 
121 upstream of Paris (Gournay-sur-Marne, Maisons-Alfort and Villeneuve-Saint-Georges), and three

122 were located downstream of Paris (Triel-sur-Seine, Levallois and Le Pecq). The three target tissues,

123 namely, stomach $(n=60)$, liver $(n=60)$ and muscle $(n=22)$, were immediately removed on board.

124 Stomachs and livers were put in distilled water-diluted formaldehyde solution (5\%), while muscles

125 were packaged in aluminum paper and frozen at $-20^{\circ} \mathrm{C}$ in the lab. All tissues were weighed (wet weight) before the isolation process.

127

Seine River:

1. Villeneuve-Saint-Georges $(\mathrm{n}=13,13,2)$

2. Levallois $(\mathrm{n}=10,10,6)$

3. Le Pecq $(\mathrm{n}=6,6,1)$

4. Triel-sur-Seine $(\mathrm{n}=11,11,7)$

Marne River:

5. Gournay-sur-Marne $(\mathrm{n}=9,9,4)$

6. Maisons-Alfort $(\mathrm{n}=11,11,2)$

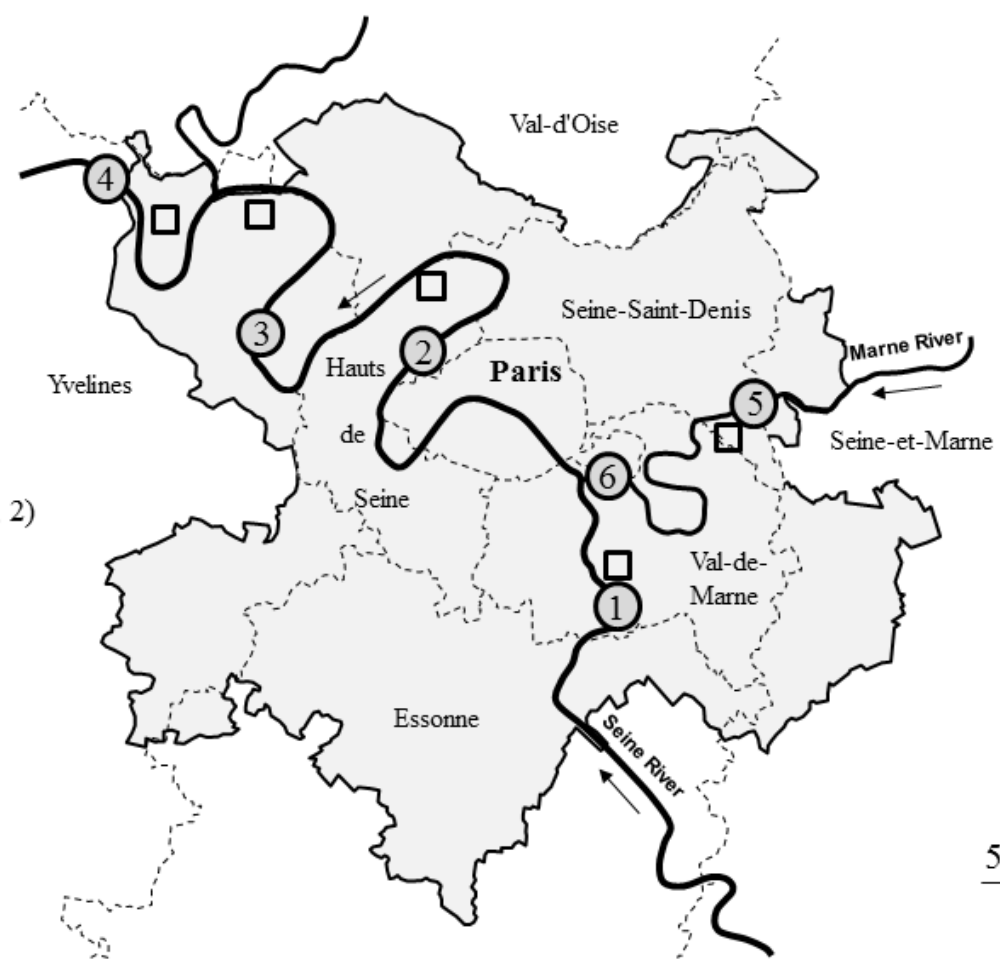

$5 \mathrm{~km}$

Figure 1. Sampling stations in the Parisian conurbation. Circles represent sampling stations and squares represent wastewater treatment plants. Number of stomach content, liver and muscle samples are shown for each station. 
135 The entirety of the stomach contents and livers were used, while only a small amount of muscle 136 sample was digested (2-4 g). All tissues were degraded using sodium hypochlorite and then filtered 137 with a 5- $\mu \mathrm{m}$ filtering membrane according to published methodology (Collard et al., 2015). 138 Nevertheless, methanol (99\%), which is typically used for the centrifugation step, was replaced by 139 ethanol (99\%), as methanol degrades polyvinylchloride (Collard et al., 2015). Indeed, ethanol is 140 commonly used to store biota samples or microplastics once analyzed (Sanchez et al., 2014; 141 Phillips and Bonner, 2015; Ory et al., 2017).

142 Consequently, in the frame of this study, tissues were put into a $14 \mathrm{~g} / \mathrm{L} \mathrm{NaClO}$ solution overnight. 143 The $\mathrm{NaClO}$ solution was filtered with a cellulose acetate filter membrane (5- $\mu \mathrm{m}$ porosity), which 144 was then rinsed with ethanol. This solution, containing APs, was centrifuged at 5,000 rpm for 10 145 min. The bottom was then collected and deposited onto a stainless steel plate for Raman 146 spectroscopy analysis.

148 Raman analysis

150 All found particles were analyzed using a LabRam 300 spectrometer (Jobin-Yvon) equipped with 151 an Olympus confocal microscope and an Andor BRDD Du401 CCD detector. Depending on the 152 color of the particle, either a Spectraphysics argon ion laser $(514.5 \mathrm{~nm})$ or a Torsana diode laser $153(784.7 \mathrm{~nm}$ ), with two different objectives (magnification of $\times 50$ or $\times 100$ ), was used. The maximum 154 beam laser powers induced on the sample were $5 \mathrm{~mW}$ (green laser) and $30 \mathrm{~mW}$ (red laser), but 155 several neutral density filters were used to decrease the power and avoid degradation of the sample. 156 The integration times ranged from $5 \mathrm{~s}$ to $50 \mathrm{~s}$, depending on the sample. Two spectral databases 
157 were used to perform matchings: a commercially available database (Omnic Specta software,

158 Thermo Fisher Scientific, U.S.A.) and a personal library, which used the Thermo Specta 2.0

159 software.

160 After Raman analyses, APs were isolated in $1 \mathrm{ml}$ of $99 \%$ ethanol for further observations and 161 measurements. Only particles whose anthropogenic origin was confirmed by Raman spectroscopy 162 (plastic particles, dyed particles, etc.) were included in the results. Those particles showing an 163 anthropogenic origin have been classified as "APs". Inside the "AP" category, we defined two 164 subcategories: microplastics and other APs (e.g., dyed particles of an unknown material). In 165 addition, we classified all APs based on their shape: either fragments or fibers.

Preventing contamination and procedural blanks

To minimize contamination, white cotton lab coats and latex gloves were worn throughout the entire isolation process. All work surfaces and dissection materials were rinsed with distilled water, and all glassware was rinsed with distilled water before each use. Stainless steel plates were placed under a metal sifter with $36-\mu \mathrm{m}$ mesh to prevent airborne contamination while the plates dried. No

173 particles smaller than $36 \mu \mathrm{m}$ were found. The $\mathrm{NaClO}$ was filtered with a 5 - $\mu \mathrm{m}$ cellulose acetate 174 membrane before dilution with distilled water.

175 Three 50-ml volumes of formaldehyde used to store the samples were filtered with the same filter 176 membrane as that used for the isolation process. No APs were found. In addition, guts and livers

177 were kept closed in the formaldehyde but were opened under an airflow cabinet just before the 178 isolation process. Muscles were kept in aluminum, but particles from this material were not found 179 in any samples. 
Three procedural blanks were performed, along with runs of several samples, meaning that the

181

182

183

184

185

186

187

188

189

190

191

192

193

194

195

196

197

198

199

200

201

202

203

entire isolation process was verified. It began in the formaldehyde solution used to store the samples and ended with the observation of stainless steel plates using Raman spectroscopy. This allowed us to evaluate whether solutions, materials or equipment were contaminated by APs in any way. Two particles made of an unknown organic material and two others made of only cellulose were found, meaning that those particles were not APs.

\section{Images and measurements of particles}

APs were collected from the Raman plates with $99 \%$ ethanol solution and then put into a microtube for further filtration using the same white filter membranes as those used for the isolation process. APs were photographed on both the stainless steel plate and on the filter membrane using a stereomicroscope (Leica MZ12, Leica AG Camera, Germany). They were then measured at their longest dimension using the Histolab software (Histolab Products AB, Sweden).

\section{Statistics}

Statistical analyses were performed with the GraphPad Prism software (v5.03, GraphPad software Inc., California, U.S.A.). Pearson's test was applied to evaluate the correlation between fish and AP lengths. Normality of the data was checked using the Kolmogorov-Smirnov test prior to analysis. Fisher's test was applied to compare (1) the number of fish that ingested (or not) at least one AP, MP, fiber or fragment, with each type of particle considered independently; (2) the number of all ingested APs versus MPs; (3) the number of ingested fibers versus fragments; and (4) the concentrations of all APs and MPs in SC, between upstream and downstream of Paris. A Mann- 
204 Whitney U test was applied to compare the lengths of ingested APs between the upstream and 205 downstream suburbs of Paris. All alpha values were set at 0.05. Data are expressed in mean \pm 206 standard deviation (SD).

207

208 Results

209

210 Stomach contents (SCs)

211

212 All isolated particles were analyzed, and 18 APs out of 70 isolated particles were found (Fig. 2).

213 The fifty-two other particles were made of natural organic polymers such as cellulose or could not

214 be identified. Twenty-five percent of fish have ingested at least one AP, and 15\% have ingested at 215 least one plastic particle.

216

217 

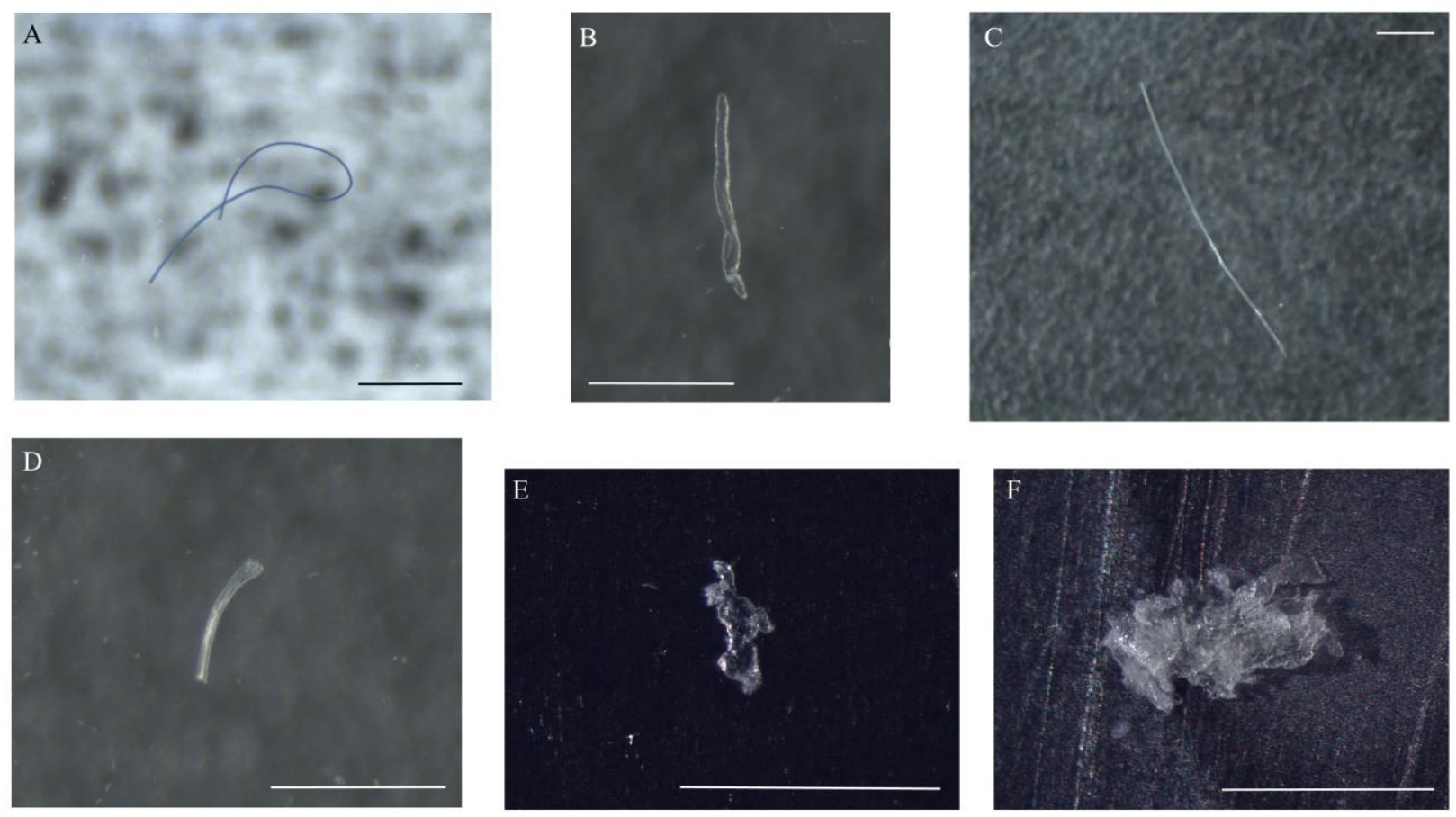

219 Figure 2. Pictures of APs found in stomach contents (A-D) and livers (E, F) of S. cephalus. A: blue

220 dyed fiber, B: polypropylene (PP) fiber, C: polyethylene terephthalate fiber, D: PP fiber, E:

221 polystyrene fragment, F: polyethylene fragment. Scale bar: $500 \mu \mathrm{m}$.

223 Table 1. Characteristics of the 18 APs found in stomach contents (SC). * Concerns only fibers.

\begin{tabular}{|c|c|c|c|c|c|}
\hline \multirow{2}{*}{ Station } & Composition & Size (mm) & $\begin{array}{c}\text { Diameter* } \\
(\boldsymbol{\mu m})\end{array}$ & Shape & Item/g SC \\
\hline \multirow{2}{*}{ Gournay- } & Plack dyed & 2.96 & 11 & FI & 0.38 \\
\cline { 2 - 6 } sur-Marne & fiber & 0.84 & 22 & FI & 2.86 \\
\cline { 1 - 6 } Maisons- & $\begin{array}{c}\text { Blue dyed } \\
\text { fragment }\end{array}$ & 2.41 & 30 & FI & \\
\hline
\end{tabular}




\begin{tabular}{|c|c|c|c|c|c|}
\hline & Blue dyed fiber & 0.96 & 18 & FI & \\
\hline & PET & 0.74 & 12 & FI & 0.71 \\
\hline \multirow{4}{*}{$\begin{array}{c}\text { Villeneuve- } \\
\text { Saint- } \\
\text { Georges }\end{array}$} & PET & 2.51 & 40 & FI & 2.5 \\
\hline & PP & 0.69 & 59 & FI & 0.38 \\
\hline & PET & 0.39 & 32 & FI & 0.67 \\
\hline & Blue dyed fiber & 1.08 & 27 & FI & 0.38 \\
\hline \multirow{4}{*}{$\begin{array}{l}\text { Triel-sur- } \\
\text { Seine }\end{array}$} & $\begin{array}{c}\text { Blue dyed } \\
\text { particle }\end{array}$ & 1.43 & 23 & FI & \multirow[t]{2}{*}{1.7} \\
\hline & Blue dyed fiber & 2.21 & 17 & FI & \\
\hline & PEVA & 6.56 & - & FR & 0.36 \\
\hline & $\mathrm{PP}$ & 0.44 & - & FR & 0.67 \\
\hline \multirow{2}{*}{ Levallois } & PET & 2.36 & 56 & FI & 1.0 \\
\hline & Blue dyed fiber & 4.44 & 22 & FI & 0.59 \\
\hline \multirow[b]{2}{*}{ Le Pecq } & Blue dyed fiber & 1.21 & 31 & FI & 3.33 \\
\hline & $\begin{array}{c}\text { Black dyed } \\
\text { fiber }\end{array}$ & 4.79 & 22 & FI & 2.0 \\
\hline
\end{tabular}

224 PET=polyethylene terephthalate, PP=polypropylene, PEVA=poly(ethylene-co-vinyl acetate), 225 PAN=polyacrylonitrile, $\mathrm{FI}=$ fiber, $\mathrm{FR}=$ fragment. 
a

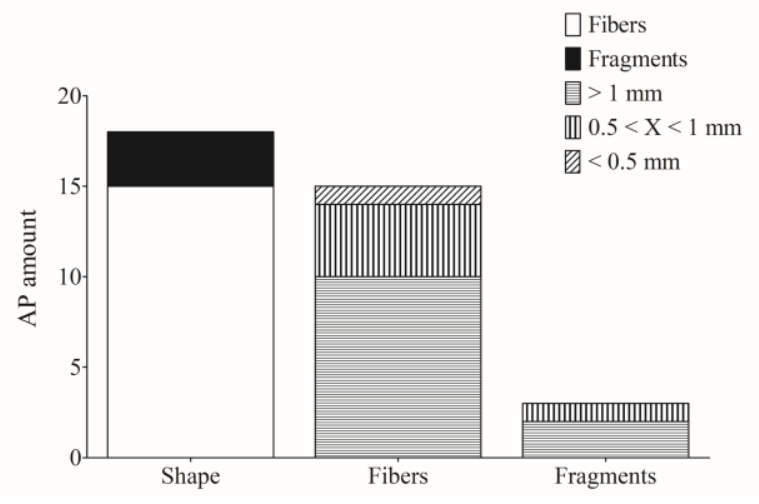

b

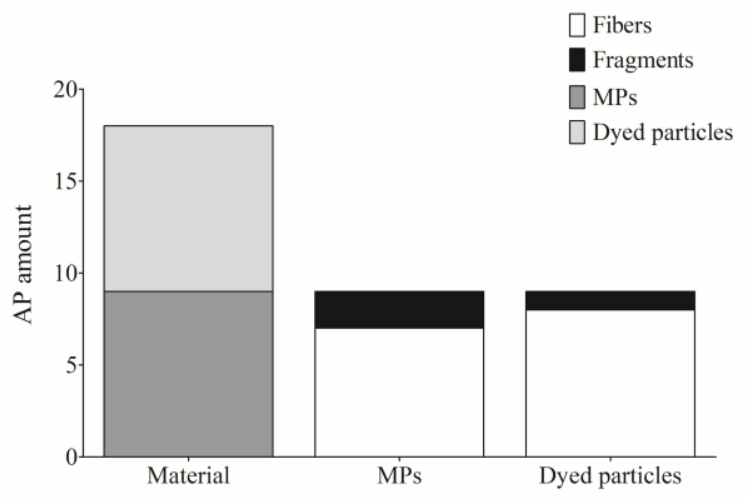

228

229 Figure 3. Summary of the main characteristics of APs found in stomach contents. a: total AP 230 amount according to shape, b: total AP amount according to composition.

Of the 18 APs, 15 were fibers, and 3 were fragments (Fig. 3a). Fibers longer than 1 mm were dominant $(\mathrm{n}=10)$, followed by fibers ranging from 0.5 to $1 \mathrm{~mm}(\mathrm{n}=4)$ and by fibers smaller than were other kinds of APs, i.e. dyed particles (Table 1, Fig. 3b). Four types of plastic polymers were 238 found (Fig. 4): polyethylene terephthalate (PET, n=5), polypropylene (PP, n=2), polyacrylonitrile 239 (PAN, n=1) and poly(ethylene-co-vinyl acetate) (PEVA, n=1). Furthermore, twenty fibers of 240 cellulose were found in SC samples but were not included in APs, because the anthropogenic origin 241 could not be confirmed using Raman spectroscopy. There is no correlation between the length of ingested APs and the length of fish $\left(\mathrm{R}^{2}=0.0026\right)$. 


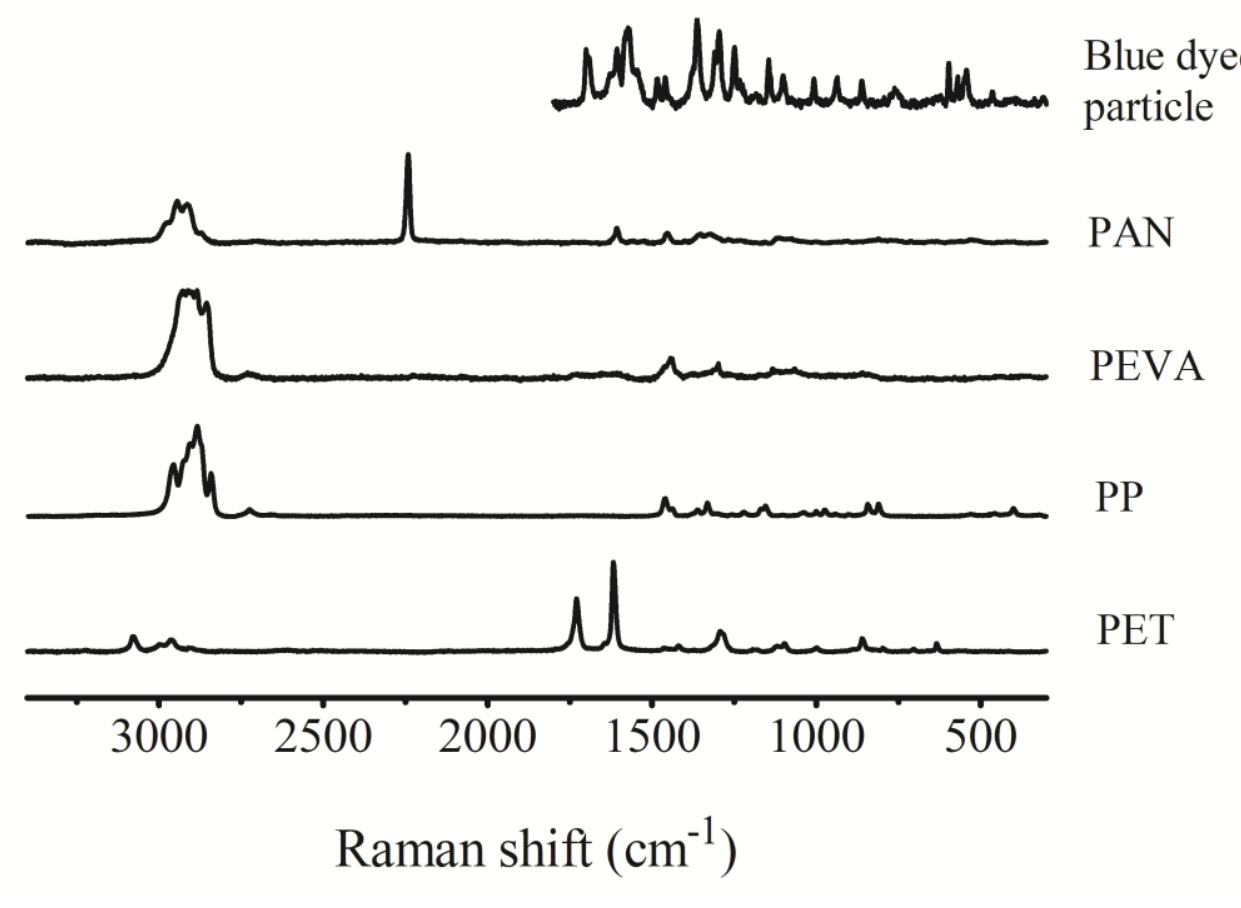

Figure 4. Raman spectra obtained from isolated APs. PET=polyethylene terephthalate, $247 \mathrm{PP}=$ polypropylene, PEVA=poly(ethylene-co-vinyl acetate), PAN=polyacrylonitrile.

249 When comparing the areas upstream and downstream of Paris, no significant difference was found 250 regarding the number of individuals having ingested MPs alone, all APs, fibers and fragments; the 251 number of ingested APs and MP; the number of ingested fibers and fragments (contingency tables, $252 \alpha>0.05$ ); and the length of all ingested APs (Mann-Whitney U test, $\alpha=0.24$ ). A summary of the 253 results is shown in Table 2. Fish from the upstream stations had $0.32 \mathrm{AP} / \mathrm{g}$ of SC, while fish from 254 the downstream stations had $0.40 \mathrm{AP} / \mathrm{g}$ of SC, also showing no significant difference (contingency 255 tables, $\alpha>0.05)$.

257 Table 2. Comparison of different data between the areas upstream and downstream of Paris. $258 \%=$ percentage. 


\begin{tabular}{|c|c|c|}
\hline & Upstream $(\mathbf{n}=\mathbf{3 3})$ & Downstream (n=27) \\
\hline \% of fish with AP & $24 \%$ & $26 \%$ \\
\hline \% of fish with MP & $18 \%$ & $11 \%$ \\
\hline Mean AP size & $2.00 \mathrm{~mm}$ & $2.93 \mathrm{~mm}$ \\
\hline Min-max size & $0.39-7.38 \mathrm{~mm}$ & $0.44-6.56 \mathrm{~mm}$ \\
\hline \% of fibers & $90 \%$ & $75 \%$ \\
\hline \% of fragments & $10 \%$ & $15 \%$ \\
\hline $\begin{array}{c}\text { AP/g of SC } \\
\text { (wet weight) }\end{array}$ & 0.32 & 0.40 \\
\hline
\end{tabular}

Livers \& Muscles

263 Four APs, of 13 total extracted particles, were found in three livers out of the sixty analyzed. All 264 were MPs, but three were made of PE, and one was made of polystyrene (PS). Their lengths ranged 265 from $147 \mu \mathrm{m}$ to $567 \mu \mathrm{m}$ (Table 3). Given the size of these MP fragments, it is very unlikely that 266 they come from airborne contamination.

268 Table 3. Characteristics of MPs found in livers.

\begin{tabular}{|c|c|c|c|}
\hline Station & Polymer & Size (mm) & Shape \\
\hline Levallois & PE & 0.567 & FR \\
& PE & 0.161 & FR \\
\hline & PE & 0.147 & FR \\
\hline
\end{tabular}




\begin{tabular}{|c|c|c|c|}
\cline { 2 - 3 } Villeneuve- & & & \\
Gaint- & PS & 0.270 & FR \\
Georges & & & \\
\hline
\end{tabular}

$269 \mathrm{FR}=$ fragment, $\mathrm{PE}=$ polyethylene, $\mathrm{PS}=$ polystyrene.

270

271 No APs were found in muscle tissue.

272

273 Discussion

274

275 No difference was found between the areas upstream and downstream of Paris. Regarding shape,

276 fibers were dominant, and fibers longer than $1 \mathrm{~mm}$ were found in a higher quantity than the two

277 other size classes. The smallest fiber found in SCs was $390 \mu \mathrm{m}$ long. Smaller particles are unlikely

278 to be ingested because they would probably be rejected with water through branchial structures

279 (Collard et al., 2017b). Although Dris et al. (2015a) did not use any spectroscopic method for

280 identification, these three results are consistent with those highlighted by the previous study in the

281 Seine River water. Their study found an average of 45 fibers $/ \mathrm{m}^{3}$ and 0.54 fragments $/ \mathrm{m}^{3}$ in the water

282 column but found no difference between the downstream and upstream areas, and fibers longer

283 than $1 \mathrm{~mm}$ were predominant. European chubs' stomach contents seem to reflect what is found in

284 the river water. Moreover, since it is not an endangered species in European waters, European chub

285 could then be used as a bioindicator for AP and MP pollution. It is already used as a common

286 bioindicator in European freshwaters for other pollutants, such as musk (Hájková et al., 2007),

287 metals (Dragun et al., 2016), dioxins and polychlorobiphenyls (Pacini et al., 2013). 
289 Compared to fibers, only a few anthropogenic fragments were found. Fragments may be indirectly 290 ingested through various pathways: transfer from prey, as shown in experimental studies (Cedervall 291 et al., 2012; Farrell and Nelson, 2013; Setälä et al., 2014); accidental ingestion from the water 292 column or from sediments; or intentional ingestion (Ory et al., 2017). The chub is an omnivorous 293 (Piria et al., 2005) and opportunistic fish (Balestrieri et al., 2006), meaning that everything is 294 potential prey to feed on, including plastic. However, mechanisms of ingestion cannot be elucidated 295 in this study.

All former studies dealing with AP ingestion by freshwater fish focused on MPs. In comparison, the next section will also focus on MP ingestion but not on all APs. Few studies exist on MP ingestion by freshwater fishes, and moreover, their results must be carefully compared. Locations, species, and methodologies, including characterization of the target particles, differ between studies, leading to inconsistent comparisons. Here, we chose to provide data in terms of items/individual, items/g SC and percentage of occurrence. Each of those units has advantages and disadvantages but will at least allow comparisons between previous and future studies. The percentage of MP occurrence is often used to make comparisons more reliable. Regarding MP ingestion by freshwater fish, some of the lowest percentages of MP occurrence are found in fish from Geneva Lake (Faure et al., 2015), from French rivers (Sanchez et al., 2014), from a Brazilian estuary (Vendel et al., 2017), and in European smelts Osmerus eperlanus from the Thames estuary (McGoran et al., 2017) (7.5\%, 12\%, 9\%, and 20\% of individuals had ingested plastics, respectively). With an MP occurrence rate of $15 \%$, our study has one of the lowest percentages. In addition, some studies have reported high MP occurrence percentages of up to $100 \%$ (Pazos et al., 2017). High values were also found in the Thames estuary, where $71 \%$ of flounders Platichthys 
313 about the possible difference between pelagic and benthic feeders. According to a study on

314 European smelts (pelagic) and flounders (benthic), feeding strategies could have an influence on 315 the ingestion of APs (McGoran et al., 2017). The benthic species had a much higher ingestion rate 316 than the pelagic one, but this was not statistically assessed. By contrast, Jabeen et al. (2017) and 317 Murphy et al. (2017) found a significant difference between demersal and pelagic fishes (in 318 freshwaters and marine waters, respectively). The demersal species ingested more APs. However, 319 our study concerned a pelagic species, and we found a relatively low rate of MP occurrence 320 compared to high percentages previously cited. Our percentage of MP occurrence in SC could have 321 been underestimated. Among the dyed particles found in our study, some may have been made of 322 a plastic polymer, which cannot be detected using Raman spectroscopy because of the dye coating.

323 In marine environments, sediments are a sink for microplastics (Woodall et al., 2014). Regarding 324 freshwaters, the literature lacks information about river sediment microplastic contamination, 325 highlighting the need for more studies to assess whether freshwater demersal feeders are more 326 exposed to pelagic ones.

328 In the SC, a higher proportion of fibers was found compared to fragments (83\% vs. 17\%), as expected based on other studies (McGoran et al., 2017; Pazos et al., 2017; Silva-Cavalcanti et al., 2017; Vendel et al., 2017). As the digestion protocol may have bleached some particles because of the use of $\mathrm{NaClO}$, some dyed cellulosic fibers may have, in actuality, been dyed textile fibers that were bleached during the isolation process, leading to an underestimation of APs. However, the 333 results concerning the type of particle ingested by chubs are consistent with what is commonly 334 found in the Seine and Marne Rivers: fibers are much more abundant than fragments.

335 WWTPs could be sources of fibers in urban rivers. While they help to retain a proportion of them, 336 e.g., from $83 \%$ to $95 \%$ (Dris et al. 2015a), WWTP effluents still constitute as a source of fibers 
338 fibers can pass through (Dris et al., 2015a). Atmospheric fallout can also be an additional source 339 of fibers in receiving systems. Indeed, Dris et al. (2016) found that $50 \%$ of fibers coming from 340 atmospheric fallout were longer than $1 \mathrm{~mm}$, which is the dominant size class ingested by chubs. In 341 that study, $50 \%$ of all fibers were natural, $21 \%$ were manufactured by transformation of natural 342 polymers (e.g., rayon), and $29 \%$ contain a petrochemical-derived polymer (e.g., mix of cotton and 343 polyamide, or polyurethane). No information regarding the $>1 \mathrm{~mm}$ size class was given. Even if 344 no direct link can be established between atmospheric fallout and the presence of long fibers in 345 chubs' SC, we speculate that atmospheric inputs in water could be an important source of the 346 longest fibers, which could then be ingested by freshwater biota.

347 The release of fibers into the environment is already a major concern, since washing machines can 348 release a high amount of fibers per wash (Hartline et al., 2016; Hernandez et al., 2017). A polyester garment can release fibers between $0.033 \%$ and $0.039 \%$ of its weight (Dubaish and Liebezeit, 350 2013), and six identical fleece garments can release fibers from $0.008 \%$ to $0.021 \%$ of their total weight (Pirc et al., 2016). Consequently, in urban environments, fibers may be more problematic than fragments, particularly for filtering organisms that have adapted their morphology to retain such particles (Collard et al., 2017b).

An increasing number of studies report AP, mainly MP, ingestion by fish, but the impacts are unknown. Studies which focus on wild-caught species probably have data regarding only a 357 snapshot of the fish's lifetime. After being ingested, MPs are probably excreted (Van 358 Cauwenberghe and Janssen, 2014; Watts et al., 2014; Grigorakis et al., 2017), but they may have 359 a longer retention time than food that is typically (Ward and Kach, 2009; Mazurais et al., 2015). 360 Additionally, no mechanical harm resulting from MPs has been reported in fish, but in birds, 
plastics can reduce hunger or cause a reduction in assimilation efficiency (Ryan, 1989; Lenzi et al., 362 2016). The problem may instead concern pollutants. Microplastic fibers, like other microplastics, 363 adsorb pollutants present in the surrounding water and contain small amounts of additives. They 364 can be transferred to organisms once ingested (Teuten et al., 2009), although this is controversial 365 (Koelmans et al., 2016). Additionally, little is known about adsorption on APs other than those that are plastic. In our study, 9 out of 18 APs were not made of plastic. How do pollutants interact with such particles? Did they also leach from particles to organs? Fibers constitute a major part of AP pollution in freshwater environments, so answering these questions is a priority for AP pollution research.

For the first time, MPs have been found in the livers of wild freshwater fish. Translocation also occurs in Parisian freshwaters, where fragment contamination is lower than fiber contamination (Dris, 2016). Translocation phenomena of such large MP abundances in fish have already occurred in both the laboratory (Avio et al., 2015) and the marine environment (Collard et al., 2017a). Other organisms also exhibit MP translocation (von Moos et al., 2012; Brennecke et al., 2015) but in the laboratory only. In mammals, the uptake of microparticles from the gut and subsequent passage 377 through Peyer's patches in the intestine mucosa has been known for several decades (LeFevre et 378 al., 1978; Jani et al., 1989; Jani et al., 1990). However, fish do not contain Peyer's patches, 379 (Rombout et al., 1993; Cairn and Swan, 2010), and MP translocation pathways through the intestinal barrier are unknown in these organisms. Some hypotheses have been proposed, such as persorption, during which particles pass between cells of the gut epithelium to the circulatory system (Volkheimer, 1975; Wright and Kelly, 2017); endocytosis, which is an internalization of particles in cells of the digestive gland and has been demonstrated in mussels (Von Moos et al., 
by Browne et al. (2008), again, in mussels. The digestive system in mussels differs significantly

386 from that of fish, but since the literature regarding MP translocation in fish is very scarce, we can 387 only rely on those few studies to piece together an explanation. Considering the large sizes of MPs 388 found in livers in this study, the first hypothesis could be the most relevant. Persorption has been 389 observed for particles of up to $130 \mu \mathrm{m}$ (Steffens, 1995 cited in Wright and Kelly, 2017). The 390 remaining possibilities seem unlikely considering the sizes of translocated particles: $3 \mu \mathrm{m}$ (Browne 391 et al., 2008) and smaller than $80 \mu \mathrm{m}$ (Von Moos et al., 2012). However, this should be confirmed 392 by experimental studies.

394 No APs were detected in muscle tissue despite the use of the sensitive Raman-based method 395 developed. However, fewer samples, compared to those of SC and liver, were collected, and only 396 several grams of muscle tissue per individual were taken to limit the amount of solution used. 397 Consequently, other studies focusing on contamination of muscle tissue, and of other organs, are 398 needed.

400 Conclusions

402 In conclusion, the opportunistic European chub ingested APs in an amount similar to that observed 403 in other freshwater species (McGoran et al., 2017). Our results reflected the main ones highlighted 404 in a study performed in the Seine and Marne Rivers inhabited by chubs. We then suggested that 405 chubs may be used as an indicator species, as they are not endangered but are in fact common 406 throughout Europe. Half of the analyzed APs were found to be made of plastic, highlighting that 407 focusing on plastic particles could underestimate the level of APs ingested, regardless of species. 408 Fibers were the predominant shape found in stomach contents and are ingested with unknown 
consequences. Fragments can translocate into other organs by unknown pathways, as shown in 410 other studies. Until now, this was not observed for fibers.

411 Many questions are yet to be answered. In the field, do MPs translocate into organs other than the 412 liver? What are the pathways of translocation? How do they impact the organism? Does the MP 413 contamination level in the environment influence the translocation process? What is the proportion 414 of ingested plastic that can translocate into the liver? Considering the current global consumption 415 of fish, humans are directly impacted by those issues. Histological analyses could provide answers 416 to these questions. Histological analyses could contribute to give answers to these questions. The 417 next step in AP contamination research could be to focus on in vitro studies, which may help to 418 evaluate impacts and determine what type(s) of particles are likely to be translocated and the 419 reasons for such translocation (polymer, size, presence of dyes on surface molecules, etc.).

421 Acknowledgments

423 The research leading to these results received funding from the People Programme (Marie Curie 424 Actions) of the European Union's Seventh Framework Programme (FP7/2007-2013) under the 425 REA grant agreement n. PCOFUND-GA-2013-609102, through the PRESTIGE programme 426 coordinated by Campus France (postdoctoral grant). The authors also want to thank the University 427 of Paris-Est Créteil (UPEC) and the SIAAP scientists who helped during the sampling survey. 
Adamek, Z., Obrdlik, P., 1977. Food of important cyprinid species in the warmed barb zone of the Oslava river. Folia Zool. 26, 171-182.

Arthur, C., Baker, J., Bamford, H. (eds), 2009. Proceedings of the International Research Workshop on the Occurrence, Effects and Fate of Microplastics Marine Debris.

Avio, C.G., Gorbi, S., Regoli, F., 2015. Experimental development of a new protocol for extraction and characterization of microplastics in fish tissues: First observations in commercial species from Adriatic Sea. Mar. Environ. Res. 111, 18-26. https://doi.org/10.1016/j.marenvres.2015.06.014

Balestrieri, A., Prigioni, C., Remonti, L., Sgrosso, S., Priore, G., 2006. Feeding ecology of Leuciscus cephalus and Rutilus rubilio in southern Italy. Ital. J. Zool. 73, 129-135. https://doi.org/10.1080/11250000600679561

Barreiros, J.P., Raykov, V.S., 2014. Lethal lesions and amputation caused by plastic debris and fishing gear on the loggerhead turtle Caretta caretta (Linnaeus, 1758). Three case reports from Terceira Island, Azores (NE Atlantic). Mar. Pollut. Bull. 86, 518-22. https://doi.org/10.1016/j.marpolbul.2014.07.020

Beck, C.A., Barros, N.B., 1991. The impact of debris on the Florida manatee. Mar. Pollut. Bull. 22, 508-510. https://doi.org/http://dx.doi.org/10.1016/0025-326X(91)90406-I

Bergmann, M., Gutow, L., Klages, M., 2015. Marine anthropogenic litter. Springer.

Brennecke, D., Ferreira, E.C., Costa, T.M.M., Appel, D., da Gama, B.A.P., Lenz, M., 2015. Ingested microplastics $(\& \mathrm{gt} ; 100 \mu \mathrm{m})$ are translocated to organs of the tropical fiddler crab Uca rapax. Mar. Pollut. Bull. 96, 491-495. https://doi.org/10.1016/j.marpolbul.2015.05.001 Browne, M.A., Dissanayake, A., Galloway, T.S., Lowe, D.M., Thompson, R.C., 2008. Ingested 
Microscopic Plastic Translocates to the Circulatory System of the Mussel, Mytilus edulis (L.). Environ. Sci. Technol. 42, 5026-5031. https://doi.org/10.1021/es800249a

Cairn, K., Swan, C., 2010. Fish Physiology: The Multifunctional Gut of Fish, Fish Physiology. Elsevier Science.

Cedervall, T., Hansson, L.-A., Lard, M., Frohm, B., Linse, S., 2012. Food chain transport of nanoparticles affects behaviour and fat metabolism in fish. PLoS One 7, e32254. https://doi.org/10.1371/journal.pone.0032254

Collard, F., Gilbert, B., Compère, P., Eppe, G., Das, K., Jauniaux, T., Parmentier, E., 2017a. Microplastics in livers of European anchovies (Engraulis encrasicolus, L.). Environ. Pollut. 229, 1000-1005. https://doi.org/10.1016/j.envpol.2017.07.089

Collard, F., Gilbert, B., Eppe, G., Parmentier, E., Das, K., 2015. Detection of Anthropogenic Particles in Fish Stomachs: An Isolation Method Adapted to Identification by Raman Spectroscopy. Arch. Environ. Contam. Toxicol. 69, 331-339. https://doi.org/10.1007/s00244-015-0221-0

Collard, F., Gilbert, B., Eppe, G., Roos, L., Compère, P., Das, K., Parmentier, E., $2017 b$. Morphology of the filtration apparatus of three planktivorous fishes and relation with ingested anthropogenic particles. Mar. Pollut. Bull. 116, 182-191. https://doi.org/10.1016/j.marpolbul.2016.12.067

Cózar, A., Echevarría, F., González-Gordillo, J.I., Irigoien, X., Ubeda, B., Hernández-León, S., Palma, A.T., Navarro, S., García-de-Lomas, J., Ruiz, A., Fernández-de-Puelles, M.L., Duarte, C.M., 2014. Plastic debris in the open ocean. Proc. Natl. Acad. Sci. U. S. A. 111, 10239-10244. https://doi.org/10.1073/pnas.1314705111

Denuncio, P., Bastida, R., Dassis, M., Giardino, G., Gerpe, M., Rodríguez, D., 2011. Plastic ingestion in Franciscana dolphins, Pontoporia blainvillei (Gervais and d'Orbigny, 1844), 
from Argentina. Mar. Pollut. Bull. 62, 1836-1841. https://doi.org/10.1016/j.marpolbul.2011.05.003

Djinova, L., 1976. Za ishranata za klenot (Leuciscus cephalus macedonicus Kar.) i mrenata (Barbus cyclolepis strumicae Kar.) od rekata i od akumulacijata Turija. Folia Balc. 3.

Dris, R., 2016. First assessment of sources and fate of macro- and micro- plastics in urban Dragun, Z., Tepić, N., Krasnići, N., Teskeredžić, E., 2016. Accumulation of metals relevant for hydrosystems: Case of Paris megacity. Université de Paris-Est Créteil.

Dris, R., Gasperi, J., Saad, M., Mirande, C., Tassin, B., 2016. Synthetic fibers in atmospheric agricultural contamination in gills of European chub (Squalius cephalus). Environ. Sci. Pollut. Res. 23, 16802-16815. https://doi.org/10.1007/s11356-016-6830-y

fallout: A source of microplastics in the environment? Mar. Pollut. Bull. 104, 290-293. https://doi.org/10.1016/j.marpolbul.2016.01.006

Dris, R., Gasperi, J., Rocher, V., Saad, M., Renault, N., Tassin, B., 2015a. Microplastic contamination in an urban area: A case study in Greater Paris. Environ. Chem. 12, 592-599. https://doi.org/10.1071/EN14167

Dris, R., Gasperi, J., Rocher, V., Tassin, B., 2018. Synthetic and non-synthetic anthropogenic fibers in a river under the impact of Paris Megacity: Sampling methodological aspects and flux estimations. Sci. Total Environ. 618, 157-164. https://doi.org/10.1016/j.scitotenv.2017.11.009

Dris, R., Imhof, H., Sanchez, W., Gasperi, J., Galgani, F., Tassin, B., Laforsch, C., 2015 b. Beyond the ocean: Contamination of freshwater ecosystems with (micro-)plastic particles. Environ. Chem. 12, 539-550. https://doi.org/10.1071/EN14172

Dubaish, F., Liebezeit, G., 2013. Suspended microplastics and black carbon particles in the Jade system, southern North Sea. Water. Air. Soil Pollut. 224. 
502

503

504

505

506

507

508

509

510

511

512

513

514

515

516

517

518

519

520

521

522

523

524

525

Eriksen, M., Mason, S., Wilson, S., Box, C., Zellers, A., Edwards, W., Farley, H., Amato, S., 2013. Microplastic pollution in the surface waters of the Laurentian Great Lakes. Mar. Pollut. Bull. 77, 177-182. https://doi.org/10.1016/j.marpolbul.2013.10.007

FAO, 2011. FAO Capture Production of Leuciscus Cephalus [WWW Document]. URL http://www.fishbase.se/report/FAO/FAOCatchList.php?scientific=Leuciscus+cephalus (accessed 9.15.17).

Farrell, P., Nelson, K., 2013. Trophic level transfer of microplastic: Mytilus edulis (L.) to Carcinus maenas (L.). Environ. Pollut. 177, 1-3. https://doi.org/10.1016/j.envpol.2013.01.046

Faure, F., Corbaz, M., Baecher, H., de Alencastro, L., 2012. Pollution due to plastics and microplastics in Lake Geneva and in the Mediterranean Sea. Arch. Sci. 65, 157-164.

Faure, F., Demars, C., Wieser, O., Kunz, M., De Alencastro, L.F., 2015. Plastic pollution in Swiss surface waters: Nature and concentrations, interaction with pollutants. Environ. Chem. 12, 582-591. https://doi.org/10.1071/EN14218

Freyhof, J., 2014. The IUCN Red List of Threatened Species 2014: Squalius cephalus [WWW Document]. URL http://www.iucnredlist.org/details/61205/0 (accessed 9.15.17).

Gasperi, J., Dris, R., Bonin, T., Rocher, V., Tassin, B., 2014. Assessment of floating plastic debris in surface water along the Seine River. Environ. Pollut. 195, 163-166. https://doi.org/10.1016/j.envpol.2014.09.001

Grigorakis, S., Mason, S.A., Drouillard, K.G., 2017. Determination of the gut retention of plastic microbeads and microfibers in goldfish (Carassius auratus). Chemosphere 169, 233-238. https://doi.org/http://dx.doi.org/10.1016/j.chemosphere.2016.11.055

Hájková, K., Pulkrabová, J., Hajšlová, J., Randák, T., Žlábek, V., 2007. Chub (Leuciscus cephalus) as a Bioindicator of Contamination of the Vltava River by Synthetic Musk 

006-0190-4

Hartline, N.L., Bruce, N.J., Karba, S.N., Ruff, E.O., Sonar, S.U., Holden, P.A., 2016. Microfiber Masses Recovered from Conventional Machine Washing of New or Aged Garments. Environ. Sci. Technol. 50, 11532-11538. https://doi.org/10.1021/acs.est.6b03045

Hernandez, E., Nowack, B., Mitrano, D.M., 2017. Polyester Textiles as a Source of Microplastics from Households: A Mechanistic Study to Understand Microfiber Release During Washing. Environ. Sci. Technol. 51, 7036-7046. https://doi.org/10.1021/acs.est.7b01750

Jabeen, K., Su, L., Li, J., Yang, D., Tong, C., Mu, J., Shi, H., 2017. Microplastics and mesoplastics in fish from coastal and fresh waters of China. Environ. Pollut. 221, 141-149. https://doi.org/http://dx.doi.org/10.1016/j.envpol.2016.11.055

Jacobsen, J.K., Massey, L., Gulland, F., 2010. Fatal ingestion of floating net debris by two sperm whales (Physeter macrocephalus). Mar. Pollut. Bull. 60, 765-7.

$$
\text { https://doi.org/10.1016/j.marpolbul.2010.03.008 }
$$

Jani, P., Halbert, G.W., Langridge, J., Florence, A.T., 1990. Nanoparticle uptake by the rat gastrointestinal mucosa: Quantitation and particle size dependency. J. Pharm. Pharmacol. $42,821-826$.

Jani, P., Halbert, G.W.W., Langridge, J., Florence, A.T.T., 1989. The Uptake and Translocation of Latex Nanospheres and Microspheres after Oral Administration to Rats. J. Pharm. Pharmacol. 41, 809-812. https://doi.org/10.1111/j.2042-7158.1989.tb06377.x

Koelmans, A.A., Bakir, A., Burton, G.A., Janssen, C.R., 2016. Microplastic as a Vector for Chemicals in the Aquatic Environment: Critical Review and Model-Supported Reinterpretation of Empirical Studies. Environ. Sci. Technol. 50, 3315-3326. https://doi.org/10.1021/acs.est.5b06069 
Kühn, S., Bravo Rebolledo, E.L., Van Franeker, J.A., 2015. Deleterious Effects of Litter on Marine Life, in: Bergmann, M., Gutow, L., Klages, M. (Eds.), Marine Anthropogenic Litter. Berlin, p. 447. https://doi.org/http://dx.doi.org/10. 1007/978-3-319-16510-3_4

Lebreton, L.C.M., van der Zwet, J., Damsteeg, J.-W., Slat, B., Andrady, A., Reisser, J., 2017. River plastic emissions to the world's oceans. Nat. Commun. 8, 15611. https://doi.org/10.1038/ncomms 15611

Lechner, A., Keckeis, H., Lumesberger-Loisl, F., Zens, B., Krusch, R., Tritthart, M., Glas, M., Schludermann, E., 2014. The Danube so colourful: A potpourri of plastic litter outnumbers fish larvae in Europe's second largest river. Environ. Pollut. 188, 177-181. https://doi.org/http://dx.doi.org/10.1016/j.envpol.2014.02.006

LeFevre, M.E., Vanderhoff, J.W., Laissue, J.A., Joel, D.D., 1978. Accumulation of 2- $\mu$ m latex particles in mouse Peyer's patches during chronic latex feeding. Experientia 34, 120-122. https://doi.org/10.1007/BF01921939

Lenzi, J., Burgues, M.F., Carrizo, D., Machín, E., Teixeira-de Mello, F., 2016. Plastic ingestion by a generalist seabird on the coast of Uruguay. Mar. Pollut. Bull. 107, 71-76. https://doi.org/10.1016/j.marpolbul.2016.04.016

Leslie, H.A., Brandsma, S.H., van Velzen, M.J.M., Vethaak, A.D., 2017. Microplastics en route: Field measurements in the Dutch river delta and Amsterdam canals, wastewater treatment plants, North Sea sediments and biota. Environ. Int. 101, 133-142. https://doi.org/10.1016/j.envint.2017.01.018

Lima, A.R.A., Barletta, M., Costa, M.F., 2015. Seasonal distribution and interactions between plankton and microplastics in a tropical estuary. Estuar. Coast. Shelf Sci. 165, 213-225. https://doi.org/10.1016/j.ecss.2015.05.018

Losos, B., Penaz, M., Kubièkova, J., 1980. Food and growth of fishes of the Jihlava river. Acta 
Sc. Nat. $14,1-46$.

575 Mann, R.H.K., 1976. Observations on the age, growth, reproduction and food of the chub

576 Squalius cephalus (L.) in the River Stour, Dorset. J. Fish Biol. 8, 265-288.

577 https://doi.org/10.1111/j.1095-8649.1976.tb03950.x

578 Mason, S.A., Garneau, D., Sutton, R., Chu, Y., Ehmann, K., Barnes, J., Fink, P., Papazissimos,

579 D., Rogers, D.L., 2016. Microplastic pollution is widely detected in US municipal

$580 \quad$ wastewater treatment plant effluent. Environ. Pollut. 218, 1045-1054.

581 https://doi.org/10.1016/j.envpol.2016.08.056

582 Mazurais, D., Ernande, B., Quazuguel, P., Severe, A., Huelvan, C., Madec, L., Mouchel, O., 583 Soudant, P., Robbens, J., Huvet, A., Zambonino-Infante, J., 2015. Evaluation of the impact of polyethylene microbeads ingestion in European sea bass (Dicentrarchus labrax) larvae. Mar. Environ. Res. 112, 78-85. https://doi.org/10.1016/j.marenvres.2015.09.009

McGoran, A.R., Clark, P.F., Morritt, D., 2017. Presence of microplastic in the digestive tracts of European flounder, Platichthys flesus, and European smelt, Osmerus eperlanus, from the River Thames. Environ. Pollut. 220, 744-751. https://doi.org/10.1016/j.envpol.2016.09.078

Michel, P., Oberdoff, T., 1995. Feeding habits of fourteen European freshwater fish species. Cybium 19, 5-46.

Morritt, D., Stefanoudis, P. V, Pearce, D., Crimmen, O.A., Clark, P.F., 2014. Plastic in the Thames: A river runs through it. Mar. Pollut. Bull. 78, 196-200.

Murphy, F., Russell, M., Ewins, C., Quinn, B., 2017. The uptake of macroplastic \& microplastic by demersal \& pelagic fish in the Northeast Atlantic around Scotland. Mar. Pollut. Bull. 122,

596 Nastova-Grorgjioska, R., Kostov, V., Georgiev, S., 1997. Nutrition of chub Leuciscus cephalus 597 (Linnaeaus, 1758) from river Babuna. Ribarstvo 55, 53-65. 
598

599

600

601

602

603

604

605

606

607

608

609

610

611

612

613

614

615

616

617

618

619

620

621

Ory, N.C., Sobral, P., Ferreira, J.L., Thiel, M., 2017. Amberstripe scad Decapterus muroadsi (Carangidae) fish ingest blue microplastics resembling their copepod prey along the coast of Rapa Nui (Easter Island) in the South Pacific subtropical gyre. Sci. Total Environ. 586, 430437. https://doi.org/10.1016/j.scitotenv.2017.01.175

Pacini, N., Abate, V., Brambilla, G., De Felip, E., De Filippis, S.P., De Luca, S., di Domenico, A., D’Orsi, A., Forte, T., Fulgenzi, A.R., Iacovella, N., Luiselli, L., Miniero, R., Iamiceli, A.L., 2013. Polychlorinated dibenzodioxins, dibenzofurans, and biphenyls in fresh water fish from Campania Region, southern Italy. Chemosphere 90, 80-88. https://doi.org/10.1016/j.chemosphere.2012.07.039

Pazos, R.S., Maiztegui, T., Colautti, D.C., Paracampo, A.H., Gómez, N., 2017. Microplastics in gut contents of coastal freshwater fish from Río de la Plata estuary. Mar. Pollut. Bull. 122, 85-90. https://doi.org/10.1016/j.marpolbul.2017.06.007

Phillips, M.B., Bonner, T.H., 2015. Occurrence and amount of microplastic ingested by fishes in watersheds of the Gulf of Mexico. Mar. Pollut. Bull. https://doi.org/10.1016/j.marpolbul.2015.08.041

Pierce, K.E., Harris, R.J., Larned, L.S., Pokras, M.A., 2004. Obstruction and starvation associated with plastic ingestion in a Northern Gannet Morus bassanus and a Greater Shearwater Puffinus gravis. Mar. Ornithol. 32, 187-189.

Pirc, U., Vidmar, M., Mozer, A., Kržan, A., 2016. Emissions of microplastic fibers from microfiber fleece during domestic washing. Environ. Sci. Pollut. Res. 23, 22206-22211. https://doi.org/10.1007/s11356-016-7703-0

Piria, M., Treer, T., Aničić, I., Safner, R., Odak, T., 2005. The natural diet of five cyprinid fish species. Agric. Conspec. Sci. 70, 21-28.

Rech, S., Macaya-Caquilpán, V., Pantoja, J.F., Rivadeneira, M.M., Jofre Madariaga, D., Thiel, 
M., 2014. Rivers as a source of marine litter - A study from the SE Pacific. Mar. Pollut. Bull. 82, 66-75.

Rochman, C.M., Hoh, E., Hentschel, B.T., Kaye, S., 2013. Long-term field measurement of sorption of organic contaminants to five types of plastic pellets: Implications for plastic

Rombout, J.H.W.M., Taverne-Thiele, A.J., Villena, M.I., 1993. The gut-associated lymphoid tissue (GALT) of carp (Cyprinus carpio L.): An immunocytochemical analysis. Dev. Comp. Immunol. 17, 55-66. https://doi.org/10.1016/0145-305X(93)90015-I

Ryan, P.G., 1989. The effects of ingested plastic and other marine debris on seabirds, in: Shomura, R.S., Godfrey, M.L. (Eds.), Proceedings of the Second International Conference on Marine Debris. Honolulu, Hawaii, pp. 623-634.

Sanchez, W., Bender, C., Porcher, J.-M., 2014. Wild gudgeons (Gobio gobio) from French rivers are contaminated by microplastics: preliminary study and first evidence. Environ. Res. 128, 98-100. https://doi.org/10.1016/j.envres.2013.11.004

Setälä, O., Fleming-Lehtinen, V., Lehtiniemi, M., 2014. Ingestion and transfer of microplastics in the planktonic food web. Environ. Pollut. 185, 77-83. https://doi.org/10.1016/j.envpol.2013.10.013

Silva-Cavalcanti, J.S., Silva, J.D.B., França, E.J. de, Araújo, M.C.B. de, Gusmão, F., 2017. Microplastics ingestion by a common tropical freshwater fishing resource. Environ. Pollut. 221, 218-226. https://doi.org/10.1016/j.envpol.2016.11.068

Steffens, K.-J., 1995. Persorption - Criticism and Agreement as Based upon In Vitro and In Vivo Studies on Mammals, in: Absorption of Orally Administered Enzymes. Springer Berlin Heidelberg, Berlin, Heidelberg, pp. 9-21. https://doi.org/10.1007/978-3-642-79511-4_2

Teuten, E.L., Saquing, J.M., Knappe, D.R.U., Barlaz, M.A., Jonsson, S., Bjorn, A., Rowland, 

Viet, P.H., Tana, T.S., Prudente, M., Boonyatumanond, R., Zakaria, M.P., Akkhavong, K., Ogata, Y., Hirai, H., Iwasa, S., Mizukawa, K., Hagino, Y., Imamura, A., Saha, M., Takada, H., 2009. Transport and release of chemicals from plastics to the environment and to wildlife. Philos. Trans. R. Soc. B Biol. Sci. 364, 2027-2045.

Van Cauwenberghe, L., Janssen, C.R., 2014. Microplastics in bivalves cultured for human https://doi.org/10.1098/rstb.2008.0284 https://doi.org/10.1016/j.marpolbul.2017.01.081

Volkheimer, G., 1975. Hematogenous dissemination of ingested polyvinyl chloride particles. consumption. Environ. Pollut. 193, 65-70. https://doi.org/10.1016/j.envpol.2014.06.010

Vendel, A.L., Bessa, F., Alves, V.E.N., Amorim, A.L.A., Patrício, J., Palma, A.R.T., 2017. Widespread microplastic ingestion by fish assemblages in tropical estuaries subjected to anthropogenic pressures. Mar. Pollut. Bull. 117, 448-455. Ann. N. Y. Acad. Sci. 246, 164-71.

Von Moos, N., Burkhardt-Holm, P., Köhler, A., 2012. Uptake and effects of microplastics on 661 cells and tissue of the blue mussel Mytilus edulis L. after an experimental exposure. Environ.

Sci. Technol. 46, 11327-11335.

Wang, W., Ndungu, A.W., Li, Z., Wang, J., 2017. Microplastics pollution in inland freshwaters of China: A case study in urban surface waters of Wuhan, China. Sci. Total Environ. 575, 1369-1374. https://doi.org/10.1016/j.scitotenv.2016.09.213

Ward, J.E., Kach, D.J., 2009. Marine aggregates facilitate ingestion of nanoparticles by suspension-feeding bivalves. Mar. Environ. Res. 68, 137-142. https://doi.org/10.1016/j.marenvres.2009.05.002

Watts, A.J.R., Lewis, C., Goodhead, R.M., Beckett, S.J., Moger, J., Tyler, C.R., Galloway, T.S., 

2014. Uptake and retention of microplastics by the shore crab Carcinus maenas. Environ.

671 Sci. Technol. 48, 8823-8830.

672 Woodall, L.C., Sanchez-Vidal, A., Canals, M., Paterson, G.L.J., Coppock, R., Sleight, V.,

673 Calafat, A., Rogers, A.D., Narayanaswamy, B.E., Thompson, R.C., 2014. The deep sea is a 674 major sink for microplastic debris. R. Soc. Open Sci. 1, 140317-140317.

675 https://doi.org/10.1098/rsos.140317

676 Wright, S.L., Kelly, F.J., 2017. Plastic and Human Health: A Micro Issue? Environ. Sci. Technol.

677 51, 6634-6647. https://doi.org/10.1021/acs.est.7b00423

678

679 